\title{
MAKALAH
}

\section{PROSES DAN METODE PEMBELAJARAN}

Diajukan untuk memenuhi tugas Ujian Tengah Semester pada mata kuliah Manajemen Sekolah yang di simpu oleh:

Wahyu Bagja Sulfemi, M.Pd.

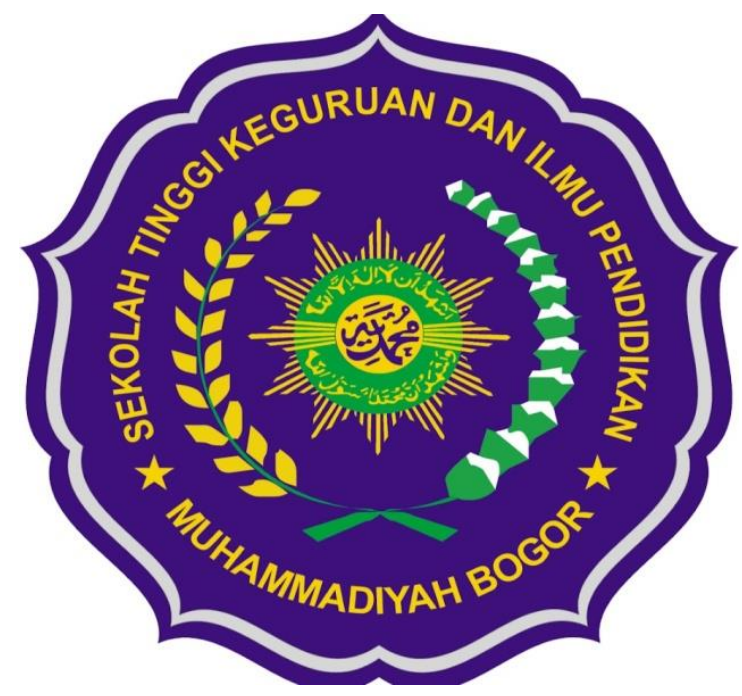

Disusun oleh : LEONALDI

$\underline{0142 S 1 A 018027}$

SEMESTER 3

STKIP Muhammadiyah Bogor

Program Studi Administrasi Pendidikan

Tahun 2019 


\section{KATA PENGANTAR}

Alhamdulillah hirobbil alamin, segala puji bagi Allah Tuhan semesta alam atas segala karunia dan rahmat-Nya sehingga penulis dapat menyusun makalah ini dengan sebaik-baiknya . Makalah yang berjudul "Proses Dan Metode Pembelajaran " disusun untuk memenuhi penilaian Ujian Tengah Semester Ganjil .

Keberhasilan penulis dalam menyelesaikan makalah ini tidak lepas dari bantuan dan partisipasi berbagai pihak, untuk itu penulis ingin menyampaikan ucapan terima kasih kepada :

\section{Pimpinan STKIP Muhammadiyah Bogor}

\section{Ketua Program Studi Administrasi Pendidikan}

3. Kepada seluruh Dosen dan Staf STKIP Muhammadiyah Bogor

4. Kedua Orang Tua tercinta

5. Mahasiswa Administrasi Pendidikan semester 3

Semoga Allah SWT melimpahkan rahmat dan karunia-Nya kepada kita semua. Dalam penyusunan makalah ini penulis menyadari bahwa makalah ini masih mepunyai kekurangan dan masih jauh dari kata sempurna . Besar harapan penulis makalah ini dapat menjadi inspirasi dan sarana pembelajaran yang bermanfaat serta berniali ibadah dihadapan Allah SWT.

Amin

Bogor, 24 November 2019

Penulis 


\section{DAFTAR ISI}

COVER

KATA PENGANTAR

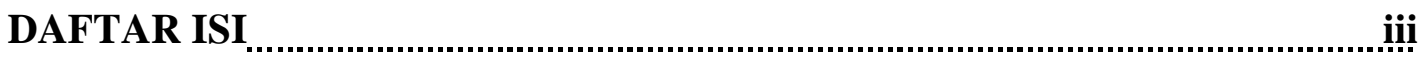

ABSTRAK

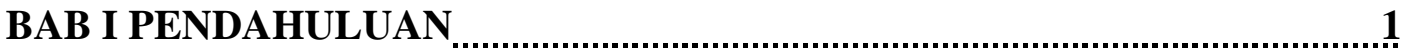

A. Latar Belakang

B. Tujuan Penulisan $\ldots$

C. Manfaat Penulisan

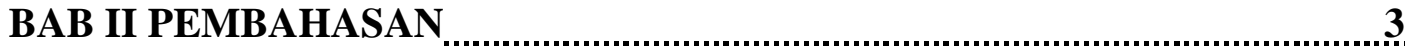

A. Pengertian Proses Pembelajaran $\ldots$

B. Pendidikan

C. Peserta Didik

D. Profesi Guru

E. Peran Guru dalam Proses Pembelajaran

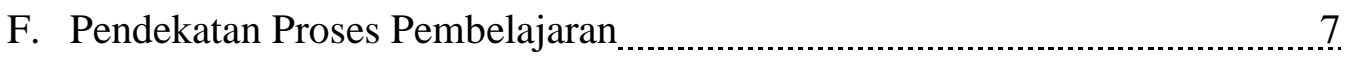

G. Metode Proses Pembelajaran

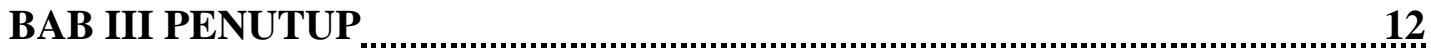

A. Kesimpulan

B. Saran 12

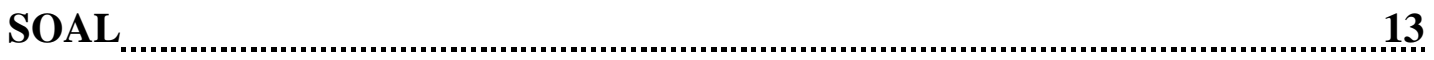

A. Pilihan Ganda

B. Essay

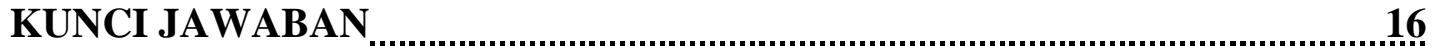

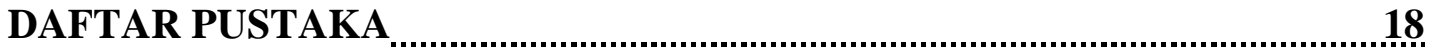




\begin{abstract}
ABSTRAK
LEONALDI, 2019. Proses Dan Metode Pembelajaran.

Proses pembelajaran merupakan proses yang mana didalamnya terdapat interaksi antara guru dan murid didalam sebuah pembelajaran untuk mencapai tujuan belajar. Proses pembelajaran itu sendiri beraneka ragam. Hal ini disebabkan, pembelajaran hakekatnya merupakan proses yang kompleks (rumit), namun dengan maksud yang sama, yaitu memberi pengalaman belajar kepada siswa sesuai dengan tujuan. Tujuan yang hendak dicapai sebenarnya merupakan acuan dalam penyelenggaraan proses pembelajaran. Oleh sebab itu, tujuan yang hendak dicapai itu berbagai macam, maka cara mencapainya pun berbagai macam pula. Proses pembelajaran juga merupakan inti dari sebuah proses pendidikan formal maupun non formal karena didalamnya terjadi interaksi berbagai komponen, yang mana komponen tersebut yaitu guru, murid, dan materi pembelajaran.
\end{abstract}




\section{BAB I}

\section{PENDAHULUAN}

\section{A. Latar Belakang}

Didalam dunia pendidikan terutamanya disekolah proses pembelajaran adalah hal inti didalam sebuah pembelajaran. Yang mana pembelajaran itu sendiri merupakan sebuah konsep dari dua dimensi kegiatan ( belajar dan mengajar) yang harus direncanakan dan diaktualisasikan, serta diarahkan pada pencapaian tujuan atau penguasaan sejumlah kompetensi dan indikatornya sebagai gambaran hasil belajar. Dan pada dasarnya pembelajaran itu merupakan kegiatan terencana yang mengkondisikan/merangsang seseorang agar bisa belajar dengan baik agar sesuai dengan tujuan pembelajaran.

Proses pembelajaran sangat beraneka ragam, itu sesuai dengan pola proses pembelajaran atau interaksi dari seorang guru dan murid. Oleh sebab itu, peran guru didalam proses pembelajaran itu sangat penting demi terwujudnya proses pembelajaran / tujuan belajar. Yang mana seorang guru itu harus mempunyai metode-metode, strategi, dan motivasi dalam proses pembelajaran tersebut. Agar tujuan dari pendidikan tersebut bisa tercapai dengan maksimal.

\section{B. Tujuan Penulisan}

Sebagai salah satu tugas Manajemen Sekolah untuk memenuhi penilaian Ujian Tengah Semester Ganjil .

\section{Manfaat Penulisan}

Penilitian ini diharapkan :

1. Menambah wawasan dan kemampuan berpikir dalam menentukan Proses pembelajaran yang efektif dan efisien . 
2. Hasil penulisan dapat digunakan untuk menambah kreativitas pengajar dalam menentukan strategi yang sesuai dalam setiap kondisi .

3. Hasil penulisan dapat di jadikan sarana pembelajaran bagi pembaca dalam mengembangkan penddikan disekolah . 


\section{BAB II}

\section{PEMBAHASAN}

\section{A . Pengertian Proses Pembelajaran}

Pembelajaran itu sendiri bermakna sebagai upaya untuk membelajarkan seseorang atau kelompok orang melalui berbagai upaya dan berbagai strategi, metode dan pendekatan ke arah pencapaian tujuan yang telah direncanakan. Pada dasarnya pembelajaran itu merupakan kegiatan terencana yang mengkondisikan/merangsang seseorang agar bisa belajar dengan baik agar sesuai dengan tujuan pembelajaran. Jadi proses pembelajaran itu sendiri merupakan sebuah proses yang didalamnya terdapat metode, strategi serta interaksi antara guru dan murid didalam sebuah pembelajaran untuk mencapai tujuan belajar.

\section{B. Pendidikan}

Pendidikan (education) secara semantik berasal dari bahasa yunani paidagogia yang berarti pergaulan dengan anak-anak. Pedagogos adalah seorang nelayan atau bujang dalam zaman yunani kuno yang pekerjaannya menjemput dan mengantar anak-anak ke dan dari sekolah. Selain itu, di rumahnya anak tersebut selalu dalam pengawasan dan penjagaan para paedagogos. Istilah ini berasal dari kata paedos yang berarti anak, dan agogos yang berarti saya membimbing atau memimpin.

Menurut Langeveld (1971: 5) pendidikan adalah setiap usaha, pengaruh, perlindungan, dan bantuan yang diberikan kepada anak tertuju kepada pendewasaan anak itu, atau lebih tepat membantu anak agar cukup, cakap melaksanakan tugas hidupnya sendiri. Pengaruh ini datangnya dari orang dewasa (orang yang diciptakan oleh orang dewasa seperti sekolah, buku, putaran hidup sehari-hari dan sebagainya) dan ditujukan kepada orang yang belum dewasa. 
Pendidikan adalah upaya yang sengaja untuk membantu pertumbuhan dan perkembangan murid. Menurut sindunata (2000:197) dalam buku Pengantar Pendidikan (2014:66) untuk mewujudkan budaya itu, proses belajar menjadi halhal yang penting.

Menurut Koentjaraningrat, (1984) dalam buku Pengantar Pendidikan (2010:6.3) yang ditulis Wahyudin Din, dkk, Dalam arti sempit kebudayaan adalah kesenian, yaitu pikiran, karya, dan hasil karya manusia yang memenuhi hasratnya akan keindahan. Adapun dalam arti luas kebudayaan adalah seluruh total pemikiran, karya, dan hasil karya manusia yang tidak berakar kepada nalurinya karna itu hanya biasa di cetuskan oleh manusia sesudah suatu proses belajar, dengan kata lain Koentjaraningrat (1985) dalam buku Pengantar Pendidikan (2010:6.3) yang ditulis Wahyudin Din, dkk, kebudayaan itu adalah dalam keseluruhan sistem gagasan, tindakan dan hasil karya manusia dalam rangka kehidupan masyarakat yang dijadikan milik diri manusia dengan belajar. (Sulfemi, $2019: 1-10$.

Pendidikan Nasional Nomor 20 Tahun 2003 pasal 1 dan 3 "pendidikan adalah usaha sadar dan terencana untuk mewujudkan suasana belajar dan proses pembelajaran agar peserta didik secara aktif mengembangkan potensi dirinya untuk memiliki kekuatan spiritual keagamaan, pengendalian diri, kepribadian, kecerdasaan, dan akhlak mulia, serta keterampilan yang diperlukan dirinya, masyarakat, bangsa dan negara”. Pendidikan nasional berfungsi mengembangkan kemampuan dan membentuk watak serta peradaban bangsa yang bermartabat dalam rangka mencerdaskan kehidupan bangsa, bertujuan untuk berkembangnya potensi peserta didik agar menjadi manusia yang beriman dan bertakwa kepada Tuhan Yang Maha Esa, Berakhlak mulia, sehat, berilmu, cakap, kreatif, mandiri, dan menjadi warga negara yang demokratis serta bertanggung jawab. (Sulfemi, $2018: 166-178)$. 


\section{Peserta Didik}

Siswa atau peserta didik merupakan salah satu komponen yang harus ada dalam dunia pendidikan . Karena tanpa peserta didik tidak akan mungkin proses belajar mengajar dapat berjalan . Peserta didik itu sendiri merupakan komponen utama dalam sebuah pendidikan karena peserta didiklah pihak yang ingin meraih cita-cita, dan memiliki tujuan yang kemudian ingin dia capai.

\section{Profesi Guru}

Dalam UU guru dan dosen, BAB I (Ketentuan Umum) pasal 1 ayat 10 bahwa pengertian kompetensi adalah seperangkat pengetahuan, keterampilan, dan perilaku yang harus dimiliki, dihayati, dan dikuasai oleh guru atau dosen dalam melaksanakan tugas keprofesionalan(Undang-Undang Guru dan Dosen, 2011 : 4).

Kompetensi merupakan kemampuan dan kewanangan guru dalam melaksanakan profesi keguruannya. Bahwa kompetensi mengacu pada kemampuan melaksanakan sesuatu yang diperoleh melalui pendidikan, kompetensi merujuk kepada performance dan perbuatan yang rasional untuk memenuhi verifikasi tertentu di dalam pelaksanaan tugas-tugas kependidikan (Hawi, $2010: 4$ )

dunia pendidikan di Indonesia masih mempunyai sekian banyak rintangan terkait dengan kualitas pendidikan diantaranya, keterbatasan akses kepada pendidikan, jumlah guru yang belum merata, juga mutu guru itu sendiri yang dinilai masih kurang. Selain itu adalah kemampuan pedagogic guru sebagai garda terdepan dalam meningkatkan sumber daya manusia. Maka dari itu kemapuan pedagoguk guru harus ditingkatkan. (Sulfemi, 2016 : 62-77).

Guru profesional harus memiliki 4 (empat) kompetensi yaitu kompetensi pedagogis, kognitif, personality, dan social. Oleh karena itu, selain terampil mengajar, seorang guru juga memiliki pengetahuan yang luas, bijak dan dapat bersosialisasi dengan baik. Sebagaimana disebutkan dalam UU No. 14 tahun 2005 tentang guru dan dosen, maka guru harus memiliki

1. Memiliki bakat, minat, panggilan jiwa, dan idealisme. 
2. Memiliki kualifikasi pendidikan dan latar belakang pendidikan yang sesuai dengan bidang tugasnya.

3. Memiliki kompetensi yang diperlukan sesuai dengan bidang tugasnya.

4. Mematuhi kode etik profesi.

5. Memiliki hak dan kewajiban dalam melaksanakan tugas.

6. Memperoleh penghasilan yang ditentukan sesuai dengan prestasi kerjanya.

7. Memiliki kesempatan untuk mengembangkan profesinya secara berkelanjutan.

8. Memperoleh perlindungan hukum dalam melaksanakan tugas profesionalnya, dan

9. Memiliki organisasi profesi yang berbadan hukum. (Sulfemi, 2015 : 71-83).

\section{E. Peran Guru dalam Proses Pembelajaran}

Proses pembelajaran merupakan inti dari proses pendidikan formal disekolah didalamnya terjadi interaksi antara berbagai komponen pembelajaran. Pada awal proses pembelajaran peran guru bisa lebih aktif. Guru memberikan pengetahuan yang dibutuhkan siswa dengan mengemukakan pendapat, bertanya, menjelaskan, memberikan contoh yang akan dipelajari siswa. Selanjutnya guru memberikan kesempatan siswa untuk aktif dan berpartisifasi secara nyata menerapkan apa yang telah dipelajarinya dari guru dengan bertanya, berpendapat, mengerjakan tugas, brlatih, atau mencoba. Ketika siswa aktif peran guru guru berubah menjadi lebih pasif dan cenderung mengawasi dan membimbing siswa tersebut.

Peran guru dalam proses pembelajaran yang dapat membangkitkan aktivitas siswa setidak-tidaknya menjalankan tugas utama, berikut ini :

1. Merencanakan Pembelajaran 
Perencanaan yang dibuat merupakan antisipasi dan perkiraan tentang apa yang akan dilakukan dalam pembelajaran, sehingga tercipta suatu situasi yang memungkinkan terjadinya proses belajara yang dapat mengantar siswa mencapai tujuan yang diharapkan.

2. Melaksanakan Pembelajaran

Pelaksanaan pembelajaran selayaknya berpegang pada apa yang tertuang pada perencanaan. Dan juga guru sepatutnya bisa menyesuaikan dalam berbagai situasi yang dihadapi, sehingga dapat menyesuaikan pola tingkah laku dalam mengajar.

Situasi pembelajaran dipengaruhi beberapa faktor :
a. Faktor Guru
b. Faktor siswa
c. Faktor kurikulum
d. Faktor lingkungan

3. Mengevaluasi Pembelajaran

Mengevaluasi pembelajaran merupakan salah satu komponen pengukur derajat keberhasilan pencapaian tujuan, dan keefektifan proses pembelajaran yang dilaksanakan.

4. Memberikan Umpan Balik

Umpan balik ini mempunyai fungsi untuk membantu siswa memelihara minat dan antusias siswa dalam melaksanakan tugas belajar.

\section{F. Pendekatan Proses Pembelajaran}

Sekolah merupakan tempat dan kesempatan belajar untuk belajar. Kegiatan belajar adalah kegiatan sepanjang hayat. Oleh karna itu kegiatan sekolah adalah lebih dari pada sekedar belajar. Kegiatan sekolah adalah kegiatan pembelajaran. 
Siswa belajar, saling belajar, bukan hanya dari guru, melainkan dari temen sekelas, sesekolah, maupun dari sumber belajar lain.

Sebagai pendekatan guru dapat menggunakan berbagai metode pembelajaran , teknik dan pendekatan pembelajaran untuk mendapatkan hasil belajar yang optimal. Guru perlu mempertimbangkan model atau metode pembelajaran yang sesuai dengan kompetensi yang dikembangkan, guru juga harus membuat perencanaan pembelajaran, penilaian, alokasi waktu, jenis penugasan, dan batas akhir tugas.

Pendekatan yang digunakan dalam pembelajaran berorientasi siswa adalahperan guru bergeser dari menentukan "apa yang akan dipelajari” ke "bagaimana menyediakan dan memperkaya pengalaman belajar siswa".

\section{G. Metode Proses Pembelajaran}

\section{Metode Pembelajaran Deskriptif}

Berdasarkan rumusan masalah di atas, peneliti memilih untuk menggunakan metode diskriptif. Metode penelitian deskriptif adalah salah satu metode penelitan yang banyak digunakan pada penelitian yang bertujuan untuk menjelaskan suatu kejadian. Seperti yang dikemukakan oleh Sugiyono (2011) “ Penelitian deskriptif adalah sebuah penelitian yang bertujuan untuk memberikan atau menjabarkan suatu keadaan atau fenomena yang terjadi saat ini dengan menggunakan prosedur iliah untuk menjawab masalah secara aktual". Metode dalam penulisan ini mendeskripsikan sebuah masalah yang terdapat dalam kemampuan frofesionalisme guru Indonesia. (Sulfemi, 2016 : 62-77).

2. Metode Pembelajaran Role Playing.

Metode Role playing adalah suatu metode bermain peran kepada peserta didik agar bisa memahami situasi sejarah sumpah pemuda pada saat itu, peserta 
didik juga dapat melatih bersosialisasi dengan mudah, Zainal Aqib dan Ali Murtadlo (2016: 186) dan diharapkan juga nilai peserta didik mencapai KKM. Salah satu contohnya yaitu belajar siswa dengan metode role palying melalui media audio. (Arsyad dan Sulfemi, $2018: 41-46$ )

\section{Metode Pembelajaran Konseptual}

Metode ini merupakan sebuah metode yang menggunakan situasi kehidupan nyata dari masyarakat setempat dimana siswa dapat mengaplikasikan pengetahuan dan keterampilan yang telah mereka kembangkan.

4. Metode Pembelajaran Ceramah

Metode pemblajaran ceramah merupakan cara yang digunakan dalam mengembangkan proses pembelajaran melalui cara penuturan (lecturer).

5. Metode Pembelajaran Demonstrasi

Metode pembelajaran demonstrasi merupakan metode penyajian pelajaran dengan memperagakan dan mempertunjukan kepada siswa tentang suatu proses, situasi, atau benda tertentu, baik sebenarnya atau sekedar tiruan.

6. Metode Pembelajaran Diskusi

Metode pembelajaran ini merupakan metode yang menghadapkan siswa pada suatu permasalahan.

7 . Metode Pembelajaran Simulasi

Metode Pembelajaran Simulasi merupakan metode pembelajaran dengan melakukan proses tingkah laku secara tiruan.

\section{Metode Tugas dan Resitasi}

Metode tugas dan resitasi sebagai metode belajar dan atau mengajar merupakan sebuah upaya membelajarkan siswa dengan cara memberikan tugas penghafalan, pembacaan, pengulangan, pengujian, dan pemeriksaan atas diri sendiri, atau menampilkan diri dalam menyampaikan sesuatu atau melakukan 
kajian maupun uji coba sesuai dengan tuntutan kualifikasi atau kompetensi yang ingin dicapai. model ini di rancang untuk merangsang siswa agar lebih aktif belajar, baik secara perorangan maupun kelompok, menumbuhkan kebiasaan untuk belajar mencari dan menemukan, mengembangkan keberanian dan tanggung jawab terhadap diri sendiri, dan memungkinkan untuk memperoleh hasil yang permanen .

9. Metode Pembelajaran Tanya Jawab

Metode tanya jawab adalah metode mengajar yang memungkinkan terjadinya komunikasi langsung yang bersifat two way traffic karena pada saat yang sama terjadi dialog antara guru dan siswa.

10. Metode Pembelajaran Kerja Kelompok

Metode kerja kelompok mengandung pengertian bahwa siswa dalam satu kelas dipandang sebagai satu kesatuan (kelompok) tersendiri maupun bagi atas kelompok-kelompok kecil (sub-sub kelompok).

\section{Metode Problem Solving (pemecahan masalah)}

Metode ini bukan hanya sekadang metode belajar tetapi juga merupakan suatu metode berpikir karena dalam problem solving dapat menggunakan metodemetode lainnnya yang yang dimulai dengan mencari data sampai pada menarik kesimpulan. Pembelajaran ini merupakan pembelajaran berbasis masalah, yakni pembelajaran berorientasi"learner sentered"dan berpusat pada pemecahan sautu masalah oleh siswa melalui kerja kelompok.

\section{Metode Latihan}

Metode latihan pada umumnya digunakan untuk memperoleh suatu ketangkasan atau keterampilan dari apa yang telah dipelajari . Metode ini digunakan untuk mengembangkan kemahiran dan keteranpilan serta dapat mengembangkan sikap dan kebiasaan . 


\section{Pembelajaran Dengan Humor}

Humor berasal ari istilah inggris yang pada mulanya memiliki beberapa arti . Sheinowizt (1996) menyatakan "humor adalah kualitas yang bersifat lucu dari seseorang yang menggelikan dan menghibur". Sementara humor dalam pembelajaran adalah komunikasi yang dilakukan guru dengan menggunakan sisipan kata-kata, bahasa dan gambar yang mampu menggelitik siswa dan tertawa sehingga dapat membuat suasana riang, rileks, dan menyenangkan dalam pembelajaran. 


\section{BAB III}

\section{PENUTUP}

\section{A. Kesimpulan}

Proses pembelajaran merupakan inti dari proses pendidikan formal disekolah didalamnya terjadi interaksi antara berbagai komponen pembelajaran. Pembelajaran itu sendiri bermakna sebagai upaya untuk membelajarkan seseorang atau kelompok orang melalui berbagai upaya dan berbagai strategi, metode dan pendekatan ke arah pencapaian tujuan yang telah direncanakan. Pada dasarnya pembelajaran itu merupakan kegiatan terencana yang mengkondisikan/merangsang seseorang agar bisa belajar dengan baik agar sesuai dengan tujuan pembelajaran. Di dalam proses pembelajaran guru mempunyai beberapa peran utama yaitu merencanakan pembelajaran, melaksanakan pembelajaran, mengevaluasi pembelajaran, dan memberikan umpan balik.

\section{B. Saran}

Dalam proses pembelajaran yang paling penting adalah dari pembelajarannya itu sendiri dan bagaimana cara seorang pengajar menyampaikan dengan baik serta dapat diterima baik oleh peserta didik. oleh sebab itu, perlu strategi pembelajaran yang tepat baik dari segi peran guru, metode, dan pendekatan yang baik untuk segala kondisi pembelajaran. 


\section{SOAL}

\section{A. Pilihan Ganda}

1. Didalam proses pembelajaran itu terdapat interaksi pembelajaran, interaksi tersebut dilakukan oleh...
a. Guru dan Murid
d. Kepala sekolah dengan Guru
b. Guru dan Guru
e. Satpam dengan Guru
c. Murid dan Murid

2. Kata pendidikan berasal dari bahasa Yunani yaitu paidagogia yang berarti...
a. Pergaulan dengan Remaja
d. Pergaulan dengan Orang Tua
b. Pergaulan dengan Orang dewasa
e. Pergaulan dengan Hewan
c. Pergaulan dengan Anak-anak

3. Dibawah ini ada 4 kompetensi guru profesional yaitu..

a. kompetensi pedagogis, kognitif, afektif ,dan budaya

b. kompetensi pedagogis, afektif, social, dan budaya

c. kompetensi pedagogis, kognitif, personality, dan social

d. kompetensi pedagogis, kognitif, masyarakat, sumber daya

e. kompetensi pedagogis, kognitif, social, dan budaya

4. Sebutkan ada berapakah yang harus dimiliki guru dalam UU No. 14 tahun 2005 tentang guru dan dosen?
a. 4
d. 8
b. 5
e. 9
c. 7 
5. Manakah yang termasuk peran guru dalam proses pembelajaran?
a. Melaksanakan Pembelajaran
d. Mengarahkan Pembelajaran
b. Memberhentikan Pembelajaran
e. Mencoba Pembelajaran
c. Mencari Pembelajaran

6. Didalam sekolah terdapat kegiatan sekolah. Kegiatan sekolah adalah Kegiatan..
a. Penjualan
d. Pembelajaran
b. Permainan
e. Pengorgaisasian
c. Penyelamatan

7. Disekolah terdapat beberapa metode pembelajaran. Ada berapakah metode pembelajaran?
a. 9
d. 12
b. 10
e. 13
c. 11

8. Metode pembelajaran diskusi merupakan metode yang mana siswanya dihadapkan dengan ...
a. Suatu Permasalahan
d. Suatu Keiklasan
b. Suatu Kondisi
e. Suatu Perkumpulan
c. Suatu Kerjasama

9. Metode pembelajaran dengan melakukan proses tingkah laku secara tiruan. Pengertian tersebut merupakan pengertian dari metode pembelajaran..
a. Simulasi
d. Ceramah
b. Demonstrasi
e. Deskriptif
c. Latihan 
10. Yang merupakan inti dari pembelajaran adalah..
a. Latihan Pembelajaran
d. Proses Pembelajaran
b. Soal Pembelajaran
e. Praktek Pembelajaran
c. Teori Pembelajaran

\section{B. ESSAY}

1. Jelaskan pengertian dari proses pembelajaran.

2. Sebutkan dan jelaskan Peran guru dalam Proses Pembelajaran?

3. Jelaskan isi dari "Pendidikan Nasional Nomor 20 Tahun 2003 pasal 1 dan 3".

4. Sebutkan faktor-faktor yang ada dalam situasi pembelajaran?

5. Sebutkan 5 saja metode-metode dalam pembelajaran? 


\section{KUNCI JAWABAN}

\section{A. Pilihan Ganda}

1. A 6. D

2. C 7. E

3. C

4. E 9. A

5. A 10. D

B. Essay

1. Proses pembelajaran merupakan proses yang mana didalamnya terdapat interaksi antara guru dan murid didalam sebuah pembelajaran untuk mencapai tujuan belajar.

2. a. Merencanakan Pembelajaran, Perencanaan yang dibuat merupakan antisipasi dan perkiraan tentang apa yang akan dilakukan dalam pembelajaran, sehingga tercipta suatu situasi yang memungkinkan terjadinya proses belajara yang dapat mengantar siswa mencapai tujuan yang diharapkan.

b. Melaksanakan Pembelajaran, Pelaksanaan pembelajaran selayaknya berpegang pada apa yang tertuang pada perencanaan. Dan juga guru sepatutnya bisa menyesuaikan dalam berbagai situasi yang dihadapi, sehingga dapat menyesuaikan pola tingkah laku dalam mengajar.

c. Mengevaluasi Pembelajaran, Mengevaluasi pembelajaran merupakan salah satu komponen pengukur derajat keberhasilan pencapaian tujuan, dan keefektifan proses pembelajaran yang dilaksanakan.

d. Memberikan Umpan Balik, Umpan balik ini mempunyai fungsi untuk membantu siswa memelihara minat dan antusias siswa dalam melaksanakan tugas belajar. 
3. "pendidikan adalah usaha sadar dan terencana untuk mewujudkan suasana belajar dan proses pembelajaran agar peserta didik secara aktif mengembangkan potensi dirinya untuk memiliki kekuatan spiritual keagamaan, pengendalian diri, kepribadian, kecerdasaan, dan akhlak mulia, serta keterampilan yang diperlukan dirinya, masyarakat, bangsa dan negara”.

4. Situasi pembelajaran dipengaruhi beberapa faktor :
a. Faktor Guru
b. Faktor siswa
c. Faktor kurikulum
d. Faktor lingkungan

5 . a. Metode pembelajaran latihan

b. Metode pembelajaran simulasi

c. Metode pembelajaran ceramah

d. Metode pembelajaran dengan humor

e. Metode pembelajaran deskriptif 


\section{DAFTAR PUSTAKA}

Majid, abdul. 2013. Strategi Pembelajaran. Bandung: PT Remaja Rosdakarya

Sumiati dan Asra. 2007. Metode Pembelajaran. Bandung. CV Wacana Prima

Sulfemi, Wahyu Bagja. (2018). Modul Manajemen Pendidikan Non Formal. Bogor:

STKIP Muhammadiyah Bogor.

Sulfemi, W. B. (2019). Manajemen Pendidikan Berbasis Multi Budaya. Bogor : STKIP Muhammadiyah Bogor.

Sulfemi, Wahyu Bagja. (2015). Kemampuan Pedagogik Guru. Prosiding Seminar Nasional. STKIP Muhammadiyah Bogor 1. (1). 71-83.

Sulfemi, Wahyu Bagja. (2016). Kompetensi Profesionalisme Guru Indonesia dalam Menghadapi MEA. Prosiding Seminar Nasional STKIP Muhammadiyah Bogor. 1 (1), 62-77.

Arsyad, Arsyad dan Sulfemi, Wahyu Bagja. (2018) Metode Role Playing Berbantu Media Audio Visual Pendidikan dalam Meningkatkan Belajar IPS. Jurnal Pendidikan Ilmu Pengetahuan Sosial Indonesia. 3 (2). 41 - 46.

Darmansyah. 2010. Strategi Pembelajaran Menyenangkan Dengan Humor. Jakarta :

PT Bumi Aksra

Lavengeld. 1971. Pendidikan

Sindunata. 2000. Buku Pengatar Pendidikan(2014:66)

Koentjaraningrat. 1984. Buku Pengantar Pendidikan(2010:6.3)

Wahyudin, dkk. Arti Sempit Kebudayaan

Koentjaraningrat.1985. Buku Penganntar Pendidikan

Pendidikan Nasional. 2003. Nomor 20 pasal 1 dan 3

UU Guru dan Dosen.2011

Hawi. 2010. Kompetensi 
UU Nomor 14.2005. Guru dan dosen

Sugiyono. 2011. Penelitian deskriptif

Zainal Aqib dan Ali Murtadlo. 2016. Metode Role Playing

Sheinowizt. 1996. Humor 